services free of charge. Museums have been established and exhibitions arranged to propagate hygienic principles, and posters and pamphlets are distributed to the villages and displayed in public places.

\section{Insect Pests of Food}

The Ministry of Food has published, under the title of "Insect Pests of Food" (London: H.M. Stationery Office, 5s. net), two important papers on moths and their larvæ affecting stored products. They are designed to provide a reliable and up-todate guide to the identification of the insects referred to. Although the two papers are primarily for the use of the Ministry's inspectors, they will be valuable to anyone concerned with the pests in question. The paper on lepidopterous larvæ affecting stored products is by Dr. H. E. Hinton and was originally published in the Bulletin of Entomological Research (34), and that on the moths by Dr. A. S. Corbett and Mr. W. H. T. Tams is reprinted from the Proceedings of the Zoological Society of London (113 B).

\section{Domestic Electrical Accessories}

THE design and installation of electrical accessories for domestic purposes was dealt with in a paper read by F. C. Fuke in London recently before the Institution of Electrical Engineers. The paper states the requirements which the design of electrical accessories must fulfil and how such requirements can be met. Contacts and switching are dealt with at some length. because of their effect upon the performance and life of most accessories. The fundamentals of fuse design are given, as well as the reason for possible indiscriminate operation between fuses of different types. The need to break away from some time-honoured practices is shown, with particular reference to plugs and tumbler switches, and solutions based on theoretical and practical considerations are presented. The author considers that British Standard Specifications should be confined to setting standards of performance, with interchangeability only where required, and that constructional details and dimensions should be omitted so as to give maximum freedom for development and, therefore, progress in design.

\section{Botanical Periodicals at Oxford}

A CATALOGUe of interest and value to all research workers and teachers in botany who wish to consult out-of-thè-way journals as well as those more easily obtained has just appeared in the "List of Periodicals" issued by the Library of the Botany Department at Oxford. The purpose of the Library is, of course, to serve in the first place the needs of the Department, and this list was naturally prepared to that end ; it is, however, now available for limited circulation. It is obvious that the privilege of borrowing books for use outside Oxford can only be granted in exceptional cases and through recognized channels; but the list will undoubtedly be of assistance to those in need of periodicals otherwise obtainable only with great difficulty and to whom these channels are available. The list is clearly annotated, the information being obtained chiefly from the periodicals themselves, and a useful feature is that all journals with current numbers in the Library are printed in bold type.

\section{Recent Earthquakes}

The United States Coast and Geodetic Survey, in co-operation with Science Service and the Jesuit Seismological Association, has determined the pro- visional epicentres of five recent earthquakes. The first, on August 7 , at $3 \mathrm{~h} .25 \cdot 3 \mathrm{~m}$. G.M.T., had its epicentre at $16.9^{\circ} \mathrm{S} ., 71 \cdot 5^{\circ} \mathrm{W}$., which is in Peru. The second, on August 10, at 1 h. $52 \cdot 7 \mathrm{~m}$. G.M.T., had its epicentre at $51 \cdot 4^{\circ} \mathrm{N} ., 130 \cdot 5^{\circ} \mathrm{W}$., which is south of Queen Charlotte Islands, off British Columbia. The third, on August 18, at 10h. 33.1m. G.M.T., had its epicentre at $35^{\circ} \mathrm{N}$., $137^{\circ}$ E., which is in Japan. The depth of focus of this shock was probably near $200 \mathrm{~km}$. The fourth shock occurred on August 24 at 23h. $37 \cdot 8 \mathrm{~m}$. G.M.T., and had its epicentre at $15^{\circ} \mathrm{N}$., $93^{\circ} \mathrm{W}$., which is in Guatemala. The depth of focus of this shock was slightly less than $100 \mathrm{~km}$. The fifth earthquake occurred on September 5 at $4 \mathrm{~h} .38 \cdot 8 \mathrm{~m}$. G.M.T. It had its epicentre at $45^{\circ} 01^{\prime}$ N., $74^{\circ} 44^{\prime} \mathrm{W}$.

On October 6, at about 5.30 a.m. local time, an earthquake in Anatolia, south of the Dardanelles and near the ruins of Troy, is reported to have destroyed. 4,000 buildings in Ayvalik, Edremit, and the surrounding district, and to have caused the deaths of 44 persons; 112 others are reported injured as a result of the earthquake. Further news of this shock is awaited.

\section{Announcements}

SIR FRED ClaARKe, director of the Institute of Education and professor of education in the University of London, will retire under the age limit on September 30, 1945, and the University has appointed Prof. G. B. Jeffery, Astor professor of mathematics at University College since 1924, to succeed him in the post of director of the Institute.

Brigadter George Macdonald, assistant director since 1939 of the Ross Institute of Tropical Hygiene, London School of Hygiene and Tropical Medicine, has been appointed director of the Institute and will take up his appointment on release from the Services.

DR. A. G. SANDERs has been appointed medical adviser in China to the British Council and has arrived in Chungking. Dr. Sanders is one of the group of Oxford workers, led by Sir Howard Florey, who developed and extended Sir Alexander Fleming's earlier work on penicillin. He was chiefly responsible for the design and construction of the apparatus used for large-scale laboratory production of penicillin. The primary object of his visit is to investigate and organize the exchange of information between China and Britain on matters of importance in medical science and practice; and he will be working under the direction of Dr. Joseph Needham, director of the British Council Cultural Scientific Office at Chungking.

SIR JoHn Russeld, who has for the past eleven weeks been in a nursing home where he has undergone a surgical operation, is sufficiently recovered to be able to return shortly to his home at Campsfield Wood, Woodstock, Oxfordshire.

THE following appointments have recently been made by the Colonial Office: R. A. Butt, to be assistant conservator of forests, Uganda; J. D. Farquhar, to be assistant conservator of forests, Palestine; G. Watkins, to be assistant conservator of forests, Tanganyika; R. D. Hodgins, to be veterinary officer, Northern Rhodesia; R. P. Lee, to be veterinary officer, Tanganyika; H. S. Darling, plant protection officer, Palestine, to be entomologist, Uganda. 